\title{
ANALISIS FAKTOR-FAKTOR YANG DIPERTIMBANGKAN KONSUMEN DALAM KEPUTUSAN PEMBELIAN MINYAK GORENG BIMOLI DI PASAR SWALAYAN KABUPATEN WONOGIRI
}

\author{
Yenny Sundari, Mohd. Harisudin, Agustono \\ Program Studi Agribisnis, Fakultas Pertanian, Universitas Sebelas Maret Surakarta \\ Jalan Ir. Sutami No.36 A Kentingan Surakarta 57126 Telp./Fax (0271) 637457 \\ E-mail: yennysundari@student.uns.ac.id
}

\begin{abstract}
The research aims to find out the considered factors and the dominant variables which considered by consumers into buying Bimoli's cooking oil at supermarket in Wonogiri regency. The basic method in this research is analytical descriptive with survey techniques. Location research purposively determined. The sampling method used was judgment sampling and data analysis method used is factor analysis. The data used are primary data and secondary data. The results of factor analysis showed that there are 7 factors that become consumer consideration in buying Bimoli cooking oil product at supermarket in Wonogiri regency. The seven factors are based on their priorities are product factors, individual factors, promotion factors, packaging factors, process factors, place factors, and psychological factors. The dominant variables considered by consumer are clarity variable on product factor, variable of income level on individual factor, advertisement display variable on promotion factor, image variable and color of packaging on packing factor, service variable on process factor, comfort variable at place factor, and Confidence variable on psychological factors.
\end{abstract}

Keywords: Factor Analysis, Marketing Mix, Factors that Affecting Consumer Behavior, Bimoli's Cooking Oil

\begin{abstract}
Abstrak: Penelitian bertujuan untuk mengetahui faktor-faktor yang diduga dipertimbangkan dan variabel-variabel yang dominan dipertimbangkan konsumen dalam membeli produk minyak goreng Bimoli di pasar swalayan Kabupaten Wonogiri. Metode dasar dalam penelitian ini adalah deskriptif analitik dengan teknik survei. Penentuan lokasi penelitian dilakukan secara purposive. Metode pengambilan sampel yang digunakan adalah judgement sampling dan metode analisis data yang digunakan adalah analisis faktor. Data yang digunakan adalah data primer dan data sekunder. Hasil analisis faktor menunjukkan bahwa ada 7 faktor yang menjadi pertimbangan konsumen dalam membeli produk minyak goreng Bimoli di pasar swalayan Kabupaten Wonogiri. Ketujuh faktor tersebut berdasarkan prioritasnya adalah faktor produk, faktor individu, faktor promosi, faktor kemasan, faktor proses, faktor tempat, dan faktor psikologis. Variabel-variabel yang dominan dipertimbangkan konsumen adalah variabel kejernihan pada faktor produk, variabel tingkat penghasilan pada faktor individu, variabel tampilan iklan pada faktor promosi, variabel gambar dan warna kemasan pada faktor kemasan, variabel pelayanan pada faktor proses, variabel kenyamanan pada faktor tempat, dan variabel keyakinan pada faktor psikologis.
\end{abstract}

Kata kunci: Analisis Faktor, Bauran Pemasaran, Faktor yang Mempengaruhi Perilaku Konsumen, Minyak Goreng Bimoli 


\section{PENDAHULUAN}

Sektor pertanian mempunyai peranan yang cukup penting dalam kegiatan perekonomian Indonesia. Salah satu sub sektor yang cukup besar potensinya adalah sub sektor perkebunan. Indonesia mempunyai komoditas perkebunan unggulan yaitu salah satunya adalah kelapa sawit. Luas perkebunan kelapa sawit terus berkembang dan kini Indonesia menjadi salah satu negara terbesar di dunia penghasil minyak kelapa sawit (Respati et al., 2014).

Kelapa sawit menghasilkan minyak kelapa sawit mentah yang diolah menjadi bahan baku minyak goreng. Minyak goreng merupakan satu dari sembilan bahan pokok yang banyak digunakan oleh rumah tangga penduduk untuk kehidupan sehari-hari. Utami (2014) menambahkan bahwa sebagian besar minyak goreng yang dikonsumsi masyarakat Indonesia adalah berasal dari sumber bahan baku sawit (minyak goreng sawit). Industri minyak goreng sawit di Indonesia terbagi menjadi dua, yaitu minyak goreng curah dan minyak goreng kemasan bermerek. Namun pemerintah telah mengeluarkan larangan peredaran minyak goreng dalam bentuk curah pada tahun 2015 (Kemendag RI, 2013), sehingga potensi pasar minyak goreng kemasan semakin terbuka lebar.

Salah satu tempat yang dipilih oleh konsumen untuk melakukan pembelian produk minyak goreng kemasan yaitu pasar swalayan. Kabupaten Wonogiri memiliki beberapa pasar swalayan. Kondisi tersebut membuat sebagian besar masyarakat memilih untuk memenuhi kebutuhan rumah tangganya dengan berbelanja di pasar swalayan karena alasan kenyamanan tempat dan produk yang tersedia lebih bervariasi, sehingga membuat adanya persaingan antar pemasar dalam merebut konsumen minyak goreng.

Kotler (1994) menyatakan keputusan pembelian merupakan hasil suatu hubungan yang saling mempengaruhi antara faktor internal yaitu budaya, sosial, pribadi, dan psikologi pembeli. Selain itu, terdapat faktor eksternal yang menimbulkan persepsi konsumen yaitu faktor stimulus pemasaran berupa produk, harga, distribusi, promosi, partisipan, proses, dan lingkungan fisik.

Penelitian ini menggunakan minyak goreng Bimoli sebagai objek penelitian karena minyak goreng Bimoli yang diproduksi oleh PT. Salim Ivomas Pratama Tbk merupakan pemimpin di pangsa pasar (market leader) minyak goreng sawit kemasan bermerek di Indonesia (Laporan Tahunan Indofood, 2013). Akan tetapi telah banyak produk sejenis muncul di pasaran yang siap merebut pangsa pasar Bimoli, terbukti bahwa Top Brand Index (TBI) dari minyak goreng Bimoli mengalami fluktuasi bahkan cenderung penurunan hingga tahun 2016 (Tabel 1). Gambaran tersebut menunjukkan bahwa posisi merek di pasaran dan minat beli konsumen terhadap minyak goreng Bimoli menurun. Hal ini menjadikan sesuatu yang menarik untuk diteliti guna mengetahui faktor-faktor apa saja yang dipertimbangkan konsumen dalam membeli minyak goreng Bimoli khususnya di pasar swalayan Kabupaten Wonogiri, sehingga dapat digunakan perusahaan sebagai strategi pemasaran yang menekankan pada faktor-faktor tersebut.

\section{METODE PENELITIAN}

Metode dasar dalam penelitian ini adalah metode deskriptif analitik dengan teknik survei.

Tabel 1. Lima Merek Top Brand Index (TBI) dalam Industri Minyak Goreng Sawit Kemasan Bermerek di Indonesia Tahun 2012-2016

\begin{tabular}{clccccc}
\hline No & Merek & $2012(\%)$ & $2013(\%)$ & $2014(\%)$ & $2015(\%)$ & $2016(\%)$ \\
\hline $\mathbf{1}$ & Bimoli* $^{*}$ & $\mathbf{5 1 , 2}$ & $\mathbf{5 2 , 0}$ & $\mathbf{4 6 , 1}$ & $\mathbf{4 8 , 2}$ & $\mathbf{4 4 , 7}$ \\
2 & Tropical & 7,4 & 8,8 & 12,2 & 10,7 & 15,1 \\
3 & Sania & 9,9 & 8,6 & 9,8 & 10,8 & 12,9 \\
4 & Filma & 11,7 & 15,2 & 11,5 & 11,7 & 12,2 \\
5 & Sunco & 4,4 & 3,8 & 5,9 & 3,0 & 5,8 \\
\hline
\end{tabular}

Sumber: Frontier Consulting Group, dalam Top Brand Award 2016

Keterangan: $*=$ Bimoli klasik atau biasa 
Penelitian ini dilaksanakan di Kabupaten Wonogiri dengan pertimbangan bahwa pengeluaran rata-rata per kapita tiap bulan untuk kelompok komoditas minyak dan lemak se-Jawa Tengah tahun 2015 yang tertinggi terdapat di Kabupaten Wonogiri yaitu sebesar Rp 15.785,00 atau 2,67\% (BPS Jawa Tengah, 2016). Kondisi tersebut menjadikan Kabupaten Wonogiri menjadi pasar potensial bagi pemasar minyak goreng Bimoli untuk memperluas pangsa pasar.

Penelitian dilakukan pada bulan Januari Tahun 2017 di pasar swalayan. Jenis pasar swalayan sebagai lokasi penelitian ditentukan secara purposive (sengaja) yaitu supermarket, dengan pertimbangan karena dalam kelas pasar modern yang sama dan ketersediaan minyak goreng Bimoli lebih kontinyu serta keberagaman ukuran kemasan mulai dari botol, refill, dan jerigen lebih banyak tersedia di supermarket daripada minimarket sehingga lebih banyak pembeli. Pasar swalayan tersebut adalah Sinar Keduwang dan Andika Putra.

Metode pengambilan sampel yang digunakan dalam penelitian adalah judgement sampling. Sampel yang digunakan dalam penelitian ini adalah konsumen yang membeli produk minyak goreng Bimoli di kedua pasar swalayan yang telah ditentukan. Penelitian ini mengambil sampel sebanyak 100 responden yang berasal dari 24 variabel dikalikan dengan empat, hasilnya ialah 96, kemudian dibulatkan menjadi 100 responden untuk memudahkan proses perhitungan dan mampu mewakili pasar swalayan yang dijadikan sebagai lokasi penelitian serta telah sesuai dengan syarat ukuran sampel minimal dalam analisis faktor. Pembagian sampel dilakukan dengan teknik quota sampling, yaitu dengan jumlah lokasi penelitian adalah dua pasar swalayan sehingga masing-masing lokasi penelitian diambil sebesar 50 responden.

\section{Uji Validitas dan Reliabilitas Kuesioner Uji Validitas}

Menurut Sujarweni (2015), uji validitas merupakan uji yang digunakan untuk mengetahui kelayakan butir-butir suatu pertanyaan dalam mendefinisikan suatu variabel. Butir-butir pertanyaan dicobakan pada 30 orang responden di luar dari pada responden yang dijadikan sampel penelitian karena menurut Effendi dan Tukiran (2012) sangat disarankan agar jumlah responden untuk di uji coba adalah minimal 30 orang, sehingga distribusi skor (nilai) akan lebih mendekati kurva normal. Cara menentukan validitas menggunakan teknik korelasi product moment melalui bantuan perangkat lunak SPSS (Statistical Product and Service Solution) versi 16, dengan melihat di kolom Corrected ItemTotal Corelation pada hasil output data dimana apabila nilai validitas ( $\mathrm{r}$ hitung) setiap pertanyaan lebih besar dari $\mathrm{r}$ tabel $(\mathrm{df}=\mathrm{n}-2$ signifikansi $5 \%, \mathrm{n}=\mathrm{jumlah}$ responden uji) maka butir pertanyaan dikatakan sudah valid.

\section{Uji Reliabilitas}

Uji reliabilitas (keandalan) merupakan ukuran suatu kestabilan dan konsistensi responden dalam menjawab yang berkaitan dengan konstruk-konstruk pertanyaan yang merupakan dimensi suatu variabel dan disusun dalam suatu bentuk kuesioner (Sujarweni, 2015). Uji reliabilitas dapat dilihat pada nilai Cronbach's Alpha dimana apabila nilai Alpha lebih besar dari 0,6 maka konstruk pertanyaan yang merupakan dimensi variabel adalah reliabel.

\section{Metode Analisis Data}

Analisis Faktor. Analisis faktor digunakan untuk menganalisis faktor-faktor yang dipertimbangkan konsumen dalam pengambilan keputusan membeli produk minyak goreng Bimoli. Simamora (2005) mengemukakan bahwa kombinasi linier dari variabel-variabel input dinyatakan dengan persamaan:

\section{$F_{j}=b_{j 1} X_{s 1}{ }^{+} b_{j 2} X_{s 2}+\ldots \ldots+b_{j k} X_{s k}$}

Fj adalah skor faktor ke-j, bj adalah koefisien skor faktor ke-j, dan Xsk adalah variabel ke-k yang telah distandarisasi. Variabel yang diamati adalah faktor produk dengan $\mathbf{X}_{\mathbf{1}}$ adalah kemasan, $\mathbf{X}_{\mathbf{2}}$ adalah gambar dan warna kemasan, $\mathbf{X}_{\mathbf{3}}$ adalah warna minyak goreng, $\mathbf{X}_{\mathbf{4}}$ adalah kejernihan, $\mathbf{X}_{\mathbf{5}}$ adalah kandungan gizi, $\mathbf{X}_{\mathbf{6}}$ adalah gengsi, $\mathbf{X}_{\mathbf{7}}$ adalah sertifikasi halal, $\mathbf{X}_{\mathbf{8}}$ adalah rasa olahan makanan. Untuk faktor harga yaitu $\mathbf{X}_{\mathbf{9}}$ adalah harga. Selanjutnya faktor promosi yaitu $\mathbf{X}_{\mathbf{1 0}}$ adalah isi pesan iklan dan $\mathbf{X}_{\mathbf{1 1}}$ adalah tampilan iklan. Faktor tempat yaitu $\mathbf{X}_{\mathbf{1 2}}$ adalah ketersediaan di pasar swalayan, $\mathbf{X}_{\mathbf{1 3}}$ adalah penataan di pasar swalayan, dan $\mathbf{X}_{\mathbf{1 4}}$ dan kenyamanan di pasar swalayan. Untuk faktor 
partisipan yaitu $\mathbf{X}_{\mathbf{1 5}}$ adalah kualitas karyawan pasar swalayan. Faktor proses yakni $\mathbf{X}_{\mathbf{1 6}}$ dengan pelayanan di pasar swalayan. Faktor lingkungan fisik yaitu $\mathbf{X}_{\mathbf{1 7}}$ adalah kondisi kebersihan rak display. Faktor budaya yaitu $\mathbf{X}_{18}$ adalah kebiasaan. Untuk faktor individu yaitu $\mathbf{X}_{19}$ adalah gaya hidup dan $\mathbf{X}_{\mathbf{2 0}}$ adalah tingkat penghasilan. Faktor sosial yakni $\mathbf{X}_{\mathbf{2 1}}$ adalah saran keluarga dan $\mathbf{X}_{\mathbf{2 2}}$ adalah saran sahabat. Untuk faktor psikologis yaitu $\mathbf{X}_{\mathbf{2 3}}$ adalah motivasi dan $\mathbf{X}_{24}$ adalah keyakinan.

Analisis variabel yang dominan dipertimbangkan oleh konsumen.

Variabel yang dominan dipertimbangkan oleh konsumen diketahui dengan melihat nilai factor loading tertinggi dari suatu variabel. Kriteria signifikansi yang diterapkan adalah signifikansi praktis dimana factor loading diatas 0,5 . Hal ini sesuai dengan yang dikemukakan oleh Hair et al. (2006) dimana angka minimal dari factor loading adalah $>0,5$ atau idealnya $\geq 0,7$.

\section{HASIL DAN PEMBAHASAN}

\section{Karakteristik Responden}

Karakteristik responden yang diteliti dalam penelitian ini meliputi jenis kelamin, umur, tingkat pendidikan, pekerjaan, pendapatan per bulan, dan jumlah anggota keluarga. Pengambil keputusan pembelian produk minyak goreng Bimoli di swalayan Kabupaten Wonogiri yang paling dominan adalah perempuan (93\%). Kelompok umur responden yang paling tinggi berada pada kisaran umur 36-56 th yaitu sejumlah 47 orang. Sebagian besar responden memiliki tingkat pendidikan SMA/SMK yakni sebanyak $58 \%$. Jenis pekerjaan responden yang paling besar sejumlah 28 orang adalah sebagai ibu rumah tangga dan diikuti oleh karyawan swasta sebesar 15 orang. Pendapatan rumah tangga responden yang paling tinggi sejumlah $32 \%$ berada pada kisaran pendapatan antara Rp 1.500.000 hingga Rp 2.500.000. Mayoritas responden memiliki jumlah anggota keluarga 4 orang yaitu sebesar $45 \%$.

\section{Pengalaman Responden}

Frekuensi pembelian produk minyak goreng Bimoli yang terbesar adalah tidak menentu dengan jumlah 56 orang responden. Mayoritas responden $(52 \%)$ biasa membeli produk miyak goreng Bimoli dengan jenis dan volume kemasan refill 2 liter. Kemudian alasan sebagian besar responden membeli produk minyak goreng Bimoli di pasar swalayan adalah karena nyaman dan praktis yaitu sejumlah $51 \%$.

\section{Hasil Uji Validitas dan Reliabilitas Kuesioner \\ Uji Validitas}

$\mathrm{R}$ tabel pada uji validitas kali ini diperoleh dari df $($ degree of freedom $)=\mathrm{n}-2=30-2=28$ dan didapat nilai 0,312 . Berdasarkan hasil uji validitas pada Tabel 2, terlihat bahwa nilai $r$ hitung dari keduapuluh empat variabel pada kuesioner yang diujicobakan semuanya lebih besar dari $\mathrm{r}$ tabel, sehingga seluruh butir pertanyaan kuesioner untuk variabel-variabel yang diduga dipertimbangkan konsumen adalah valid.

\begin{tabular}{|c|c|c|c|}
\hline No & Variabel & r hitung & $\mathrm{r}$ tabel \\
\hline 1. & Kemasan & 0,497 & 0,312 \\
\hline 2. & $\begin{array}{l}\text { Gambar dan Warna } \\
\text { Kemasan }\end{array}$ & 0,372 & 0,312 \\
\hline 3. & Warna & 0,598 & 0,312 \\
\hline 4. & Kejernihan & 0,623 & 0,312 \\
\hline 5. & Kandungan gizi & 0,349 & 0,312 \\
\hline 6. & Gengsi & 0,421 & 0,312 \\
\hline 7. & Sertifikasi Halal & 0,442 & 0,312 \\
\hline 8. & $\begin{array}{l}\text { Rasa Olahan } \\
\text { Makanan }\end{array}$ & 0,691 & 0,312 \\
\hline 9. & Harga & 0,654 & 0,312 \\
\hline 10. & Isi Pesan Iklan & 0,560 & 0,312 \\
\hline 11. & Tampilan Iklan & 0,658 & 0,312 \\
\hline 12. & Ketersediaan & 0,497 & 0,312 \\
\hline 13. & Penataan & 0,513 & 0,312 \\
\hline 14. & Kenyamanan & 0,580 & 0,312 \\
\hline 15. & Kualitas Karyawan & 0,605 & 0,312 \\
\hline 16. & Pelayanan & 0,471 & 0,312 \\
\hline 17. & $\begin{array}{l}\text { Kebersihan Rak } \\
\text { Diplay }\end{array}$ & 0,470 & 0,312 \\
\hline 18. & Kebiasaan & 0,467 & 0,312 \\
\hline 19. & Gaya Hidup & 0,397 & 0,312 \\
\hline 20. & $\begin{array}{l}\text { Tingkat } \\
\text { Penghasilan }\end{array}$ & 0,470 & 0,312 \\
\hline 21. & Saran Keluarga & 0,589 & 0,312 \\
\hline 22. & $\begin{array}{l}\text { Saran } \\
\text { Sahabat/Rekan }\end{array}$ & 0,487 & 0,312 \\
\hline 23. & Motivasi & 0,530 & 0,312 \\
\hline 24. & Keyakinan & 0,501 & 0,312 \\
\hline
\end{tabular}

Sumber: Analisis Data Primer, 2017

\section{Uji Reliabilitas}

Tabel 3 menunjukkan bahwa nilai Cronbach's Alpha adalah sebesar 0,909. Nilai tersebut lebih 
besar dari 0,6 sehingga konstruk pertanyaan yang merupakan dimensi variabel adalah reliabel.

Tabel 3. Hasil Uji Reliabilitas

\begin{tabular}{cc}
\hline Cronbach's Alpha & Nof items \\
\hline 0,909 & 24 \\
\hline
\end{tabular}

Sumber: Analisis Data Primer, 2017

\section{Analisis Faktor}

Pada pengujian pertama analisis faktor terdapat 4 variabel yang dikeluarkan karena nilai MSA yg kurang dari 0,5 , yaitu variabel sertifikasi halal, ketersediaan, kebiasaan, dan saran sahabat atau rekan sehingga harus dilakukan pengujian ulang tanpa keempat variabel tersebut. Kemudian pengujian kedua diperoleh hasil analisis faktor yang terlihat pada Tabel 4, menunjukkan bahwa terdapat 7 faktor yang dipertimbangkan oleh konsumen dalam membeli minyak goreng Bimoli beserta variabel-variabel yang terkandung di dalamnya. Faktor produk merupakan faktor pertama yang dipertimbangkan oleh responden. Faktor ini memiliki nilai eigenvalue 3,902 dengan proporsi varian $19,510 \%$. Sesuai dengan penelitian Tamrin (2015) bahwa faktor produk berpengaruh terhadap keputusan pembelian minyak goreng Bimoli karena memiliki manfaat serta keunggulan yang meliputi rasa, kemasan, warna, dan standar SNI.
Variabel kejernihan merupakan variabel yang paling dominan karena memiliki factor loading tertinggi sebesar 0,859. Minyak goreng Bimoli merupakan minyak goreng yang bening, bersih, dan tidak keruh. Kejernihan minyak goreng Bimoli menunjukkan kualitas minyak goreng yang bersih karena diproses dengan dua kali penyaringan (multi proses) yang menjamin kehigienisan produk dalam proses produksi. Hal ini didukung dengan hasil penelitian Bardhani et al. (2009) menyatakan bahwa pertimbangan awal bagi konsumen dalam melakukan pembelian minyak sawit merah (MSM) adalah karena tingkat kejernihan produk.

Variabel dengan factor loading di urutan kedua adalah variabel warna dengan nilai 0,784. Produk minyak goreng Bimoli sendiri memiliki warna yang khas yaitu kuning keemasan. Responden menyatakan bahwa warna tersebut merupakan warna minyak goreng sawit yang ideal dibandingkan warna yang lain. Pada kenyataannya, minyak goreng Bimoli memang berwarna kuning keemasan dikarenakan barasal dari beta karoten alami.

Nilai faktor loading sebesar 0,703 menjadikan variabel rasa olahan makanan sebagai variabel terakhir yang dipertimbangkan oleh konsumen dalam faktor produk.

Tabel 4. Nilai Factor Loading untuk Setiap Variabel

\begin{tabular}{|c|c|c|c|c|c|}
\hline Faktor & $\begin{array}{l}\text { Nama } \\
\text { Faktor }\end{array}$ & $\begin{array}{l}\text { Proporsi } \\
\text { Varian }\end{array}$ & $\begin{array}{l}\text { Variabel yang Terlibat } \\
\text { pada Faktor Inti }\end{array}$ & $\begin{array}{l}\text { Factor } \\
\text { Loading }\end{array}$ & Eigenvalue \\
\hline \multirow[t]{3}{*}{1} & Produk & $19,510 \%$ & Warna & 0,784 & 3,902 \\
\hline & & & Kejernihan & 0,859 & \\
\hline & & & Rasa olahan makanan & 0,703 & \\
\hline \multirow[t]{4}{*}{2} & Individu & $10,340 \%$ & Gengsi & 0,614 & 2,068 \\
\hline & & & Gaya hidup & 0,595 & \\
\hline & & & Tingkat penghasilan & 0,766 & \\
\hline & & & Saran keluarga & 0,751 & \\
\hline \multirow[t]{3}{*}{3} & Promosi & $9,018 \%$ & Kandungan gizi & 0,516 & 1,804 \\
\hline & & & Isi pesan iklan & 0,748 & \\
\hline & & & Tampilan iklan & 0,765 & \\
\hline \multirow[t]{2}{*}{4} & Kemasan & $8,592 \%$ & Kemasan & 0,706 & 1,718 \\
\hline & & & Gambar dan warna kemasan & 0,762 & \\
\hline \multirow[t]{3}{*}{5} & Proses & $6,684 \%$ & Kualitas karyawan & 0,528 & 1,337 \\
\hline & & & Pelayanan & 0,749 & \\
\hline & & & Kebersihan rak display & 0,734 & \\
\hline \multirow[t]{2}{*}{6} & Tempat & $6,359 \%$ & Penataan & 0,814 & 1,272 \\
\hline & & & Kenyamanan & 0,850 & \\
\hline \multirow[t]{2}{*}{7} & Psikologis & $5,260 \%$ & Motivasi & 0,664 & 1,052 \\
\hline & & & Kayakinan & 0,857 & \\
\hline
\end{tabular}

Sumber: Analisis Data Primer, 2017 
Rasa olahan makanan yang digoreng menggunakan minyak goreng Bimoli memiliki rasa yang lezat dan gurih. Sedangkan untuk bahan makanan yang ditumis dengan minyak goreng Bimoli juga menghasilkan menu masakan yang tidak terlalu basah (berminyak) dan tidak sakit di tenggorokan setelah mengkonsumsi hasil masakan tersebut.

Faktor individu merupakan faktor kedua yang menjadi pertimbangan konsumen dengan nilai eigenvalue 2,068. Faktor ini mempunyai proporsi varian sebesar $10,340 \%$ dengan variabelnya yang terdiri dari variabel gengsi, variabel gaya hidup, variabel tingkat penghasilan, dan variabel saran keluarga. Hal ini sesuai dengan penelitian Budi (2016) dimana faktor pribadi dengan variabel pekerjaan dan gaya hidup mempengaruhi tingkat keputusan pembelian minyak goreng Bimoli di Samarinda.

Variabel tingkat penghasilan merupakan variabel dalam faktor individu yang dominan dipertimbangkan konsumen dengan nilai factor loading 0,766. Menurut responden, tingkat penghasilan yang diperoleh responden sesuai untuk membeli minyak goreng Bimoli. Hal ini karena biasanya responden memutuskan untuk melakukan pembelian minyak goreng Bimoli dengan direncanakan terlebih dahulu dan disesuaikan dengan alokasi dana yang dimiliki. Hal ini selaras dengan hasil penelitian Dwinada (2012) bahwa variabel pendapatan merupakan faktor sosial ekonomi berperan dalam mempengaruhi keputusan konsumen terhadap pembelian minyak goreng Bimoli di Kota Bogor, dimana besarnya pendapatan membuat konsumen dapat membeli minyak goreng kemasan merek Bimoli.

Variabel kedua dalam faktor individu yang dipertimbangkan konsumen dengan nilai factor loading 0,751 adalah variabel saran keluarga. Responden mengatakan bahwa dalam pembelian produk minyak goreng Bimoli dipengaruhi oleh saran dari keluarga. Hal tersebut karena keluarga merupakan pribadi yang dekat dengan responden dimana menjadi tempat saling bertukar pikiran sehingga saran dari mereka menjadi salah satu pertimbangan dalam membeli produk minyak goreng Bimoli.

Variabel gengsi dengan nilai factor loading 0,614 menjadi variabel ketiga dalam faktor individu yang dipertimbangkan oleh responden. Responden mengatakan bahwa dengan membeli minyak goreng Bimoli cukup menaikkan gengsi untuk pribadinya sendiri saat sedang melakukan pembelian di pasar swalayan. Responden menambahkan bahwa minyak goreng Bimoli merupakan minyak goreng kemasan dengan merek paling terkenal dan kualitas yang selalu terjaga dari tahun ke tahun sehingga menimbulkan kebanggaan tersendiri ketika membeli produk tersebut.

Variabel terakhir yang dipertimbangkan konsumen dalam faktor individu adalah variabel gaya hidup dengan factor loading 0,595 . Responden memilih minyak goreng Bimoli untuk memenuhi kebutuhan memasak karena kualitas minyak goreng Bimoli yang bebas kolesterol, tanpa bahan pengawet, dan dilengkapi dengan vitamin $\mathrm{E}$ yang sangat mendukung pola hidup sehat konsumen. Hal sesuai dengan hasil penelitian Bukhori (2017) bahwa variabel gaya hidup berpengaruh terhadap keputusan pembelian minyak goreng Bimoli dikarenakan konsumen mengutamakan gaya hidup sehat dengan menggunakan minyak goreng kemasan bermerek untuk pemenuhan kebutuhan memasak di dalam rumah tangga yang lebih terjamin kebersihannya sehingga membuat konsumen akhirnya membeli minyak goreng Bimoli.

Faktor promosi menjadi faktor ketiga yang dipertimbangkan oleh konsumen dengan nilai eigenvalue 1,804. Faktor ini memiliki proporsi varian sebesar $9,018 \%$ dengan variabelnya kandungan gizi, variabel isi pesan iklan, dan variabel tampilan iklan.

Variabel tampilan iklan merupakan variabel dalam faktor promosi yang dominan dipertimbangkan oleh konsumen dengan nilai factor loading 0,765 . Komunikasi melalui iklan di televisi memilki daya tarik rasional yang mampu menarik perhatian konsumen dengan menunjukkan kualitas produk melalui tutorial singkat memasak dengan minyak goreng Bimoli dan dihasilkan masakan yang tampak lezat disertai efek komunikasi yang tajam dan musik yang dinamis. Sesuai dengan hasil penelitian yang dilakukan oleh Hermayani (2014), bahwa iklan televisi berpengaruh signifikan terhadap keputusan pembelian minyak goreng Sania karena melalui iklan di televisi tersebut dapat menarik minat konsumen dan meningkatkan pembelian minyak goreng Sania. 
Variabel berikutnya yang menjadi pertimbangan konsumen dalam faktor promosi adalah isi pesan iklan dengan factor loading 0,748. Menurut responden, isi pesan yang terkandung dalam iklan produk minyak goreng Bimoli mampu memberikan informasi produk yang jelas kepada konsumen. Hal ini berkaitan dengan kelengkapan iklan yang menyampaikan teknologi pengolahan produk, kandungan nutrisi yang terkandung di dalamnya, dan keunggulan produk ini ketika digunakan untuk mengolah makanan.

Variabel kandungan gizi dengan nilai factor loading 0,516 menjadi variabel ketiga dalam faktor promosi yang dipertimbangkan oleh responden. Responden menyatakan bahwa minyak goreng Bimoli kaya akan kandungan gizi dan bebas kolesterol. Pada kenyataannya memang minyak goreng Bimoli merupakan produk minyak goreng sawit yang kaya akan vitamin yaitu berupa lemak tidak jenuh tunggal (Omega 9), lemak tidak jenuh ganda (Omega 6), beta karoten alami (provitamin A), dan vitamin E. Hal tersebut sesuai dengan hasil penelitian Sastri (2003) bahwa konsumen mempersepsikan Bimoli sebagai minyak goreng dengan merek terkenal yang mudah didapat, serta memiliki kandungan zat gizi yang tinggi dan tidak mengandung kolesterol, sehingga konsumen mempersepsikan minyak goreng Bimoli sebagai minyak goreng yang sehat.

Faktor kemasan merupakan faktor keempat yang menjadi pertimbangan konsumen dengan nilai eigenvalue 1,718 dan proporsi varian sebesar $8,592 \%$. Hal ini didukung oleh hasil penelitian Supriyana (2006) bahwa atribut kemasan diperhatikan oleh konsumen dalam proses pembelian minyak goreng bermerek di Kota Bogor karena konsumen cenderung membeli minyak goreng bermerek yang biasanya memiliki kemasan yang cukup menarik dan bersih.

Variabel gambar dan warna kemasan merupakan variabel dalam faktor kemasan yang dominan dipertimbangkan oleh konsumen dengan nilai faktor loading 0,762. Gambar dan warna kemasan produk minyak goreng Bimoli memiliki tampilan yang baik dan menarik. Kemasan produk minyak goreng Bimoli terdiri dari tulisan tegak bersambung "Bimoli" berwarna merah sebagai ciri khas merek, gambar lobster berwarna orange yang menunjukkan kesan setelah digoreng menggunakan minyak goreng Bimoli serta gambar kentang goreng, sosis goreng, dan beberapa sayuran seperti sawi, seledri, tomat di sekitarnya. Daya tarik visual dari kemasan produk mampu menarik perhatian konsumen untuk membelinya sehingga desain kemasan minyak goreng Bimoli banyak ditiru oleh produk pesaing.

Variabel kedua dalam faktor kemasan yang dipertimbangkan responden dengan nilai factor loading 0,705 adalah variabel kemasan. Beragam jenis kemasan memberikan alternatif pilihan bagi konsumen untuk berbelanja produk minyak goreng Bimoli yang sesuai dengan kebutuhan konsumsi serta daya belinya. Kemasan produk minyak goreng Bimoli memiliki daya tarik praktis berupa kemasan botol, refill, dan jerigen yang terbuat bahan plastik higienis yang menjamin dapat melindungi isi produk, tidak mudah bocor, mudah untuk dibawa oleh responden ketika melakukan pembelian tanpa bantuan keranjang belanja atau troli.

Faktor proses menjadi faktor kelima yang dipertimbangkan oleh konsumen dengan nilai eigenvalue 1,337 dan proporsi varian sebesar $6,684 \%$. Hal ini sesuai dengan hasil penelitian Wijaya et al. (2014) dimana faktor process dengan variabel kondisi rak display dan kecepatan transaksi pembayaran berpengaruh secara signifikan terhadap keputusan pembelian konsumen produk apel Malang di Giant MOG Kota Malang.

Variabel yang dominan dipertimbangkan konsumen dalam faktor proses yaitu variabel pelayanan dengan nilai factor loading 0,749. Menurut responden keseluruhan pelayanan pasar swalayan selama proses pembelian minyak goreng Bimoli adalah memuaskan. Keseriusan pelayanan pasar swalayan dalam pemenuhan kebutuhan pembeli tersebut mampu menimbulkan penilaian positif dari para konsumen, sehingga tidak segan untuk kembali berbelanja minyak goreng Bimoli di pasar swalayan.

Variabel kebersihan rak display dengan nilai factor loading 0,734 menjadi variabel kedua dalam faktor proses yang dipertimbangkan oleh responden. Responden menyatakan bahwa rak display penempatan minyak goreng Bimoli cukup bersih sehingga mencerminkan bahwa setiap harinya senantiasa dijaga kebersihannya. Hal ini sesuai dengan 
penelitian Yuniarti dan Aprianti (2003) bahwa kebersihan unit rak pajangan berpengaruh terhadap keputusan pembelian minuman berkarbonasi Coca-Cola.

Variabel ketiga yang menjadi pertimbangan konsumen dalam faktor proses adalah variabel kualitas karyawan berupa factor loading 0,528. Responden berpendapat bahwa karyawan jaga di bagian kelompok minyak goreng yang membantu selama proses membeli minyak goreng Bimoli di pasar swalayan Kabupaten Wonogiri adalah baik. Selain itu, cara penampilan yang rapi dan gaya bahasa yang sopan selama membantu konsumen juga menjadi pertimbangan penting bagi konsumen untuk berbelanja minyak goreng Bimoli di pasar swalayan. Hal ini selaras dengan hasil penelitian Sukotjo dan Radix (2010) yang mengemukakan bahwa faktor partisipan dengan indikator-indikatornya seperti siap membantu, keramahan dan kesediaan membantu, uniform, simpatik, dan memberi solusi dipertimbangkan oleh konsumen dalam keputusan berbelanja.

Faktor tempat merupakan faktor keenam yang menjadi pertimbangaan responden dengan nilai eigenvalue 1,272 dan proporsi varian sebesar $6,359 \%$. Hal tersebut selaras dengan hasil penelitian Damayanti (2009) bahwa faktor tempat dengan variabel kenyamanan dan penataan produk minyak goreng di pasar swalayan dipertimbangkan konsumen dalam membeli minyak goreng di pasar swalayan Kota Surakarta.

Variabel kenyamanan merupakan variabel dalam faktor tempat yang dominan dipertimbangkan responden dengan nilai factor loading 0,850 . Menurut responden, kenyamanan berbelanja di swalayan dengan berbagai fasilitas yang disediakan seperti area yang luas, adanya musik, dan ruangan ber-AC menjadi alasan kuat responden memilih berbelanja produk minyak goreng Bimoli di pasar swalayan. Area belanja yang luas dan suasana yang sejuk membuat konsumen nyaman dan tidak perlu berdesakan selama berbelanja.

Variabel kedua dalam faktor tempat yang dipertimbangkan responden dengan nilai factor loading 0,814 adalah variabel penataan. Penataan dari produk minyak goreng Bimoli di pasar swalayan menurut responden terlihat rapi dan teratur menurut jenis kemasannya pada rak serta dilengkapi dengan keterangan harga dan ukuran produk. Kondisi ini terkait dengan display produk yang berada pada letak yang strategis dimana berada satu kelompok dengan produk minyak goreng sejenis sehingga produk minyak goreng Bimoli mudah dilihat dan dijangkau oleh konsumen.

Faktor psikologis menjadi faktor ketujuh yang dipertimbangkan oleh konsumen dengan nilai eigenvalue dari faktor proses yaitu 1,052 dan proporsi varian sebesar 5,260\%. Hal tersebut didukung dengan hasil penelitian Kurniawati (2014) bahwa faktor psikologis dengan variabel motivasi, persepsi, pembelajaran, dan sikap berpengaruh positif dan signifikan terhadap keputusan pembelian minyak goreng Fortune.

Variabel keyakinan merupakan variabel dalam faktor psikologi yang dominan dipertimbangkan responden dengan nilai factor loading 0,857. Responden mengatakan bahwa merasa yakin memilih dan menggunakan minyak goreng Bimoli untuk memasak hidangan makan rumah tangganya. Hal tersebut berkaitan dengan hasil masakan dengan minyak goreng Bimoli sangat baik dan sesuai untuk selera seluruh anggota keluarga. Kotler dan Amstrong (2008) menyatakan bahwa keyakinan yang difomulasikan seseorang tentang produk dan jasa tertentu, menyebabkan keyakinan membentuk citra produk dan merek, sehingga hal tersebut dapat mempengaruhi perilaku pembelian.

Varaibel kedua dalam faktor psikologis yang dipertimbangkan responden dengan nilai factor loading 0,708 adalah variabel motivasi. Responden menyatakan bahwa memiliki motivasi untuk membeli minyak goreng Bimoli karena produk tesebut memiliki kualitas yang baik dan menginginkan hasil olahan makanan untuk konsumsi rumah tangganya juga baik. Engel et al. (1994) menyatakan bahwa ekspresi motivasi dalam pembelian dan pemakaian produk adalah karena adanya manfaat yang diharapkan, yaitu manfaat utilitarian dan manfaat hedonik atau pengalaman.

\section{KESIMPULAN DAN SARAN}

\section{Kesimpulan}

Berdasarkan hasil penelitian dan pembahasan dapat ditarik kesimpulan:

1. Faktor-faktor yang dipertimbangkan konsumen dalam keputusan pembelian 
produk minyak goreng Bimoli berdasarkan prioritasnya adalah faktor produk, faktor individu, faktor promosi, faktor kemasan, faktor proses, faktor tempat, dan faktor psikologis. Faktor harga tidak dipertimbangkan konsumen karena variabel penyusunnya berupa variabel harga memiliki factor loading kurang dari 0,5 sehingga harus dikeluarkan dari faktor.

2. Variabel-variabel yang dominan dipertimbangkan oleh konsumen untuk faktor produk adalah variabel kejernihan, faktor individu adalah variabel tingkat penghasilan, faktor promosi adalah variabel tampilan iklan, faktor kemasan adalah variabel gambar dan warna kemasan, faktor proses adalah variabel pelayanan, faktor tempat adalah variabel kenyamanan, dan faktor psikologis adalah variabel keyakinan.

\section{Saran}

Saran yang dapat diberikan yaitu:

1. Produsen hendaknya memaksimalkan faktor produk, faktor promosi, faktor kemasan, faktor proses, dan faktor tempat sebagai alat pemasaran terkendali serta memperhitungkan faktor individu dan faktor psikologis yang kemudian merancang strategi pemasaran melalui setiap variabel dominan yang dipertimbangkan oleh konsumen pada setiap faktor sehingga mampu meningkatkan penjualan dan loyalitas konsumen terhadap minyak goreng Bimoli.

2. Variabel dominan setiap faktor:

a. Untuk faktor produk dengan variabel kejernihan, produsen hendaknya menjaga kualitas bahan dan teknologi pengolahan sehingga kualitas kejernihan minyak goreng tetap terjaga.

b. Untuk faktor individu dengan variabel tingkat penghasilan, produsen hendaknya memberikan promo potongan harga setiap periode waktu tertentu di pasar swalayan sehingga dapat menarik setiap lapisan konsumen untuk melakukan pembelian.

c. Untuk faktor promosi dengan variabel tampilan iklan, produsen hendaknya dapat menyajikan bukti survei konsumen bahwa produk minyak goreng Bimoli merupakan produk yang paling disukai dibandingkan merek dari produk sejenis lain.

d. Untuk faktor kemasan dengan variabel gambar dan warna kemasan, produsen diharapkan mencantumkan keterangan vitamin A, omega 9, dan omega 6 di tampilan depan kemasan.

e. Untuk faktor proses dengan variabel pelayanan, produsen hendaknya menambah karyawan atau pramuniaga khusus dari pihak minyak goreng Bimoli di setiap swalayan sehingga dapat dilakukan promosi secara tatap muka atau langsung kepada konsumen.

f. Untuk faktor tempat dengan variabel kenyamanan, produsen diharapkan menambahkan outlet atau kotak tersendiri dengan desain yang menarik untuk menempatkan produk minyak goreng Bimoli.

g. Untuk faktor psikologis dengan variabel keyakinan, produsen sebaiknya mencantumkan label Top Brand Award di setiap jenis kemasannya.

\section{DAFTAR PUSTAKA}

BPS Jawa Tengah. 2016. Statistik Kesejahteraan Rakyat Jawa Tengah 2015. Koordinator Badan Pusat Statistik Jawa Tengah.

Bardhani, M. A; Zakaria, F. R; dan Palupi, N. S. 2009. Analisis Persepsi Konsumen terhadap Produk Minyak Sawit Merah Sebagai Minyak Kesehatan (Studi Kasus: Perumahan Ciomas Permai, Bogor). Jurnal Manajemen IKM 4(2): 185-194.

Budi, H. D. 2016. Analisis Pengaruh Faktor Sosial, Pribadi, dan Psikologis terhadap Keputusan Pembelian Produk Minyak Goreng Bimoli di Samarinda. Skripsi Terapan Manajemen Pemasaran Jurusan Administrasi Bisnis Politeknik Negeri Samarinda.

Bukhori, M. 2017. Faktor-Faktor yang Dipertimbangkan dalam Keputusan Pembelian Minyak Goreng Bimoli pada Ibu Rumah Tangga Desa Kebonagung Kec. Purworejo Kota Pasuruan. Jurnal JIBEKA 11(2): 11-20. 
Damayanti, A. 2009. Analisis Faktor Marketing Mix terhadap Keputusan Pembelian Minyak Goreng pada Pasar Swalayan di Kota Surakarta. Skripsi Fakultas Pertanian Universitas Sebelas Maret Surakarta.

Dwinada, F. 2012. Analisis Faktor - Faktor Keputusan Pembelian Minyak Goreng Kemasan Merek Bimoli (Studi Kasus: Rumah Tangga di Kota Bogor). Skripsi Manajemen Fakultas Ekonomi dan Manajemen IPB.

Effendi, S. dan Tukiran. 2012. Metode Penelitian Survei. Jakarta: LP3ES.

Engel, J. F; Blackwell, R. D; dan Miniard, P. W. 1994. Perilaku Konsumen. Jakarta: Binarupa Aksara.

Hair, J; Black, J; Babin, W. C; Anderson, B. J; dan Tatham, R. L. 2006. Multivariate Data Analysis 6 th. New Jersey: Pearson Education.

Hermayani, L. 2014. Pengaruh Tayangan Iklan Minyak Goreng Sania di Media Televisi terhadap Keputusan Pembelian Oleh Ibu Rumah Tangga di Kec. Tambang Kab. Kampar. Skripsi thesis UIN Sultan Syarif Kasim Riau.

Kemendag RI. 2013. Kemendag Mendorong Masyarakat untuk Beralih dari Minyak Goreng Curah ke Minyak Goreng Kemasan. www.kemendag.go.id. Diakses tanggal 17 Oktober 2016.

Kotler, P. 1994. Manajemen Pemasaran: Analisis, Perencanaan, Implementasi, dan Pengendalian (Edisi ke-6 Jilid 1). Jakarta: Erlangga.

Kotler, P. dan Amstrong, G. 2008. PrinsipPrinsip Pemasaran (Edisi ke-12 Jilid 1). Jakarta: Erlangga.

Kurniawati, H. 2014. Pengaruh Faktor Psikologis terhadap Keputusan Pembelian Produk Minyak Goreng Fortune pada Masyarakat Desa Sari Makmur Kec. Pangkalan Lesung Kab.
Pelalawan. Skripsi Jurusan Manajemen Fakultas Ekonomi dan Ilmu Sosial UIN Sultan Syarif Kasim Pekanbaru.

Laporan Tahunan Indofood. 2013. Laporan Tahunan Indofood Company Profile Indonesia Investments. $w w w . i n d o n e s i a-$ investments.com. Diakses tanggal 25 November 2016.

Respati, E; Hasanah, L; Wahyuningsih, S; Sehusman; Manurung, Supriyati, M. Y; dan Rinawati. 2014. Buletin Konsumsi Pangan 5(2): 36-46.

Sastri, P. N; Djohar, S; dan Ratnawaty, A. 2003. Kajian Perilaku Konsumen Minyak Goreng Bimoli dan Implikasinya terhadap Strategi Pemasaran Produk Bimoli. Tesis pada Program Manajemen Bisnis, Sekolah Pascasarjana IPB, Bogor.

Simamora, B. 2005. Analisis Multivariat Pemasaran. Jakarta: PT. Gramedia Pustaka.

Sujarweni, V. W. 2015. SPSS untuk Penelitian. Yogyakarta: Penerbit Pustaka Baru Press.

Sukotjo, H. dan Radix, S. R. 2010. Analisa Marketing Mix-7P (Produk, Price, Promotion, Place, Partisipant, Process, dan Physical Evidence) terhadap Keputusan Pembelian Produk Klinik Kecantikan Teta di Surabaya. Jurnal Mitra Ekonomi dan Manajemen Bisnis 1(2): 216-228.

Supriyana, E. 2006. Analisis Faktor-Faktor yang Mempengaruhi Perilaku Konsumen dalam Pembelian Minyak Goreng Bermerek dan Tidak Bermerek (Kasus: Rumah Makan di Kota Bogor). Skripsi Program Studi Ekstensi Manajemen Agribisnis Fakultas Pertanian IPB.

Tamrin, I. 2015. Pengaruh Bauran Pemasaran terhadap Keputusan Pembelian Minyak Goreng Bimoli di Kota Gorontalo. Skripsi Universitas Negeri Gorontalo.

Top Brand Award. 2016. Top Brand Award: Top Brand Concept. www.topbrand- 
Yenny S., Mohd. Harisudin, Agustono: Analisis Faktor-Faktor Yang Dipertimbangkan...

award.com. Diakses tanggal 25 November 2016.

Utami, T. P. 2014. Konversi Minyak Goreng Curah ke Kemasan Sederhana. www.kemendag.go.id. Diakses tanggal 16 Oktober 2016.

Wijaya, G. D. P; Astuti, R; dan Silalahi, R. L. R. 2014. Strategi Pemasaran Berdasarkan Analisis Bauran Pemasaran terhadap Keputusan Pembelian Konsumen Produk Buah Apel Malang di Giant Mall
Olympic Garden (MOG). Jurnal Teknologi Industri Pertanian, $F$. Teknologi Pertanian, Universitas Brawijaya: 1-5.

Yuniarti, R. D. dan Aprianti, R. S. 2003. Pengaruh In Store Display terhadap Keputusan Pembelian Minuman Berkarbonasi Coca-Cola (Survei pada Konsumen di Carrefour Paris Van Java Sukajadi Bandung). Jurnal Pendidikan Manajemen Bisnis 3(5): 68-83. 